\title{
Research on the Influence of Collaborative Learning among Bachelor of Education (Management) Students in University of Cape Coast, Ghana
}

\author{
Emmanuel Nana Kwesi Ofori Darko, Xiande Wang \\ School of Teacher Education, Huzhou University, Huzhou, China \\ Email: nkwesi55@gmail.com,wxdjyx555@163.com
}

How to cite this paper: Darko, E. N. K. O., \& Wang, X. D. (2021). Research on the Influence of Collaborative Learning among Bachelor of Education (Management) Students in University of Cape Coast, Ghana. Open Journal of Business and Management, 9, 2816-2833.

https://doi.org/10.4236/ojbm.2021.96157

Received: August 18, 2021

Accepted: November 5, 2021

Published: November 8, 2021

Copyright $\odot 2021$ by author(s) and Scientific Research Publishing Inc. This work is licensed under the Creative Commons Attribution International License (CC BY 4.0).

http://creativecommons.org/licenses/by/4.0/ (c) (i) Open Access

\begin{abstract}
The study's major goal was to evaluate the usage of collaborative learning among University of Cape Coast B. Ed. Management students. The investigation was conducted using a descriptive survey design. 245 student-teachers in levels 200 - 400 were sampled using a stratified simple random sampling technique. The data was collected using questionnaires created by the researchers. The replies to the research questions were determined using descriptive statistics, specifically frequencies and percentages, mean of means, and standard deviations. According to the findings, University of Cape Coast B. Ed Management students show a favorable attitude toward collaborative learning. Collaborative learning, according to the study, provides a more learner-centered environment, improves students' academic skills, develops strong working relationships among students, and increases class participation. Group activities assist students acquire intrinsic motivation, extrinsic motivation, and management skills, among other things. Finding consensus, communicating with group members, coordination between group members, lack of leadership, lack of motivation, lack of time, procrastination, scheduling conflicts, and unequal participation are among the challenges students face when using collaborative learning, according to the study. The study concluded that the academic board of the University of Cape Coast's Department of Business Education should evaluate B. Ed Management in order to make teacher-centered techniques such as collaborative learning a major pedagogy for B. Ed Management teaching and learning.
\end{abstract}

\section{Keywords}

Collaborative Learning, Students-Teachers Learning, University of Cape Coast, B.Ed. Management 


\section{Introduction}

Education is the transfer of knowledge from those who already know something to those who want to learn more. Collaborative learning could be used to accomplish this. As a result, teachers can structure lessons in a competitive, individualistic, or collaborative manner. Lesson planning decisions of teachers can have an impact on students' social interactions, knowledge, and attitudes (Carson, 1990; Johnson \& Johnson, 1987). Students in competitive classrooms believe that they can only achieve their objectives if the others in the class fail to meet theirs (Johnson et al., 1984). Students in independently structured classes work on their own goals, which are unrelated to those of their peers (Johnson \& Johnson, 1992). In a collaborative learning classroom, students work together to attain group goals that they would not be able to reach if they were working alone or competitively. Students in this classroom arrangement discuss topic matter, assist one another in learning, and encourage one another (Johnson et al., 1984).

As an instructional style, collaborative learning allows students to build abilities in group interactions and collaboration that are necessary in today's environment (Imel, 1991; Kerka, 1990). Collaborative learning experiences, according to Johnson and Johnson (1994), foster more positive views about the instructional experience than competitive or individualistic techniques. Furthermore, collaborative learning should improve student accomplishment and information retention (Dishon \& O'Leary, 1984; Johnson \& Johnson, 1992; Slavin, 1991). Students are more likely to gain critical thinking abilities and metacognitive learning methods, such as learning how to learn, in small group collaborative settings than in lectures, according to McKeachie (1978). Collaborative learning also allows students to complete practical processes and conduct reliable research, making it easier for educators to supervise their students' learning. CL also encourages students to actively participate in problem solving, resulting in a greater comprehension of the subjects (Davidson \& Major, 2014). As a result, cooperative learning may be assumed to be a better technique that will help students, but only if it is correctly executed.

Despite the advantages of collaborative learning, it appears that its use is limited. In Saudi Arabia, for example, traditional learning is the most widely used technique in college education (You \& Kang, 2014). According to Hossain and Tarmizi (2013), cooperative learning has a considerable impact on mathematics achievement and attitudes toward mathematics in Bangladesh; nevertheless, students rarely apply it in their subject study. In Nigeria, Nwosu et al. (2013) discovered that the cooperative instructional strategy of student team achievement divisions (STAD) resulted in superior performance of learners in science than standard teaching methods. In addition, after participating in cooperative learning, students indicated improved interest, motivation, and self-efficacy. Enu, Asominiwa and Obeng (2015) discovered that students who were taught utiliz- 
ing small group cooperative learning scored significantly higher on the accomplishment post-test than students who were taught using the traditional mode of instruction in Ghana. However, it appears that no empirical study on the use of collaborative learning by B. Ed Management students has been undertaken at the University of Cape Coast. In this context, the researchers wanted to see how collaborative learning was used by B. Ed. Management students at the University of Cape Coast.

\subsection{Research Questions}

The study's major goal is to look into and evaluate the usage of collaborative learning among University of Ghana B. Ed. Management students. The study was specifically led by the research questions given below.

1) What is the attitude of University of Cape Coast B. Ed. Management students toward collaborative learning?

2) What are the advantages of collaborative learning for B. Ed. Management students at the University of Cape Coast?

3) What challenges do University of Cape Coast B. Ed. Management students have when it comes to collaborative learning?

\subsection{Conceptual Framework}

The researcher studied three variables that bring collaborative learning among B.Ed. management students in the University of Cape coast. All these variables by the researcher, has been presented in a visual format (Figure 1).

\subsection{Limitations of the Study}

The study's weaknesses were primarily due to the generalization of the study's conclusions and the instrument used to collect data from the respondents. In terms of the study's findings being generalized, the truth remains that the study's relatively small sample size may prevent the results from being applied to other teacher-training departments at the University of Cape Coast, teacher-training institutions in Ghana, or other African countries. As a result, the study's conclusions were limited to the study's sample population. Questionnaire-based research

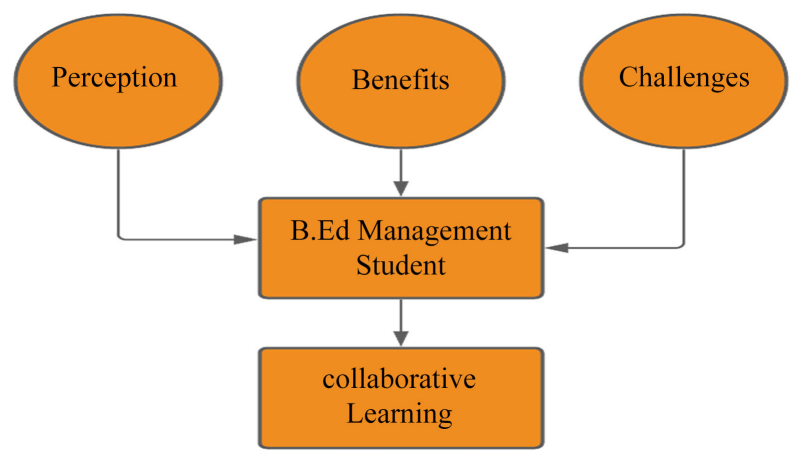

Figure 1. Conceptual framework. 
does not provide in-depth information about the instrument (Johnson \& Christensen, 2012). This means that if respondents were interviewed, the results would have been more in-depth and accurate because the researcher would have had the opportunity to ask follow-up questions to clarify responses. Furthermore, the instrument was primarily made up of components with closed ends. This means that respondents were compelled to make judgements on the items without being given the opportunity to express themselves. This could have resulted in the loss of important information that the research did not address. To compensate for this limitation, the questionnaire was designed to be thorough enough to cover the majority of important topics.

\section{Literature Review}

\subsection{Theoretical Framework: Slavin's Model of Cooperative/Collaborative Learning}

This research was based on Stevens and Slavin's (1995) Cooperative/Collaborative Learning Model. According to Stevens and Slavin's (1995) collaborative learning model, cooperative learning leads to learning gains because the collaborative process promotes motivation and subsequent cognitive activity. This notion is supported by Bandura's self-efficacy theory, Covington's (1992) self-worth theory, Vygotsky's (1978) zone of proximal development, and Piaget's (1964) social transmission theory. While competition might encourage students to focus on their own achievement rather than the failures of others, cooperative learning strives to foster a culture of high expectations among team members. Every student, both little successes and high successes, is expected to be loved and valued by their collaborative if a teacher executes a collaborative learning approach appropriately. Higher achievers are admired and appreciated for their knowledge, their talent and willingness to share it; Low performers are appreciated and valued for who they are and what they are trying to accomplish. Students are aware that their peers want them to learn and achieve. They grow enthusiastic about supporting and encouraging one another in their educational endeavours (Slavin, 1995).

Cognitive elaboration theories complement Slavin's (1995) collaborative learning paradigm. Walling (1987) said that group members discussing the topic matter during the collaborative work process helps pupils voice and elaborate their early, immature thoughts. A student appears to have opportunities to develop concepts from hazy to concrete and from preliminary to advance during the elaboration phase, which may not occur when a student simply pay attention to a lecture and inactively takes information. Active information processing, cognitive restructuring and concept reprocessing are all aided by elaboration. These, in turn, can assist a student in learning more effectively and remembering content for a longer period of time than if they were working alone (Dansereau, 1988). In a recent empirical investigation, elaboration was found to be positively associated with student achievement (Veenman, Denessen, Van Den Akker, \& Van Der 
Rijt, 2005). Slavin's cooperative learning paradigm has been supported by cognitive and motivational theories, as well as a significant number of experimental studies in many countries. Despite this, the use of collaborative learning in Ghana remains largely unexplored.

\subsection{Empirical Review}

This portion of the chapter focuses on studies that have been done on the subject in the past. This is very significant in the study because it will serve as a benchmark for comparison. The empirical review is organized around the research questions that were developed to lead the investigation.

\subsubsection{Perception of Students towards Collaborative Learning}

Phipps, Phipps, Kask and Higgins (2001) conducted a study on university students' perceptions on the consequences of cooperative learning for administrators and teachers. The goal of this study was to look at how college students felt about cooperative learning approaches, as well as how cooperative learning motivated them to study and whether it was useful to their learning. The objective was to examine how students saw the method and techniques as a tool for educators to determine what would be more stimulating. This intended to examine if the students said they studied more, were more motivated to study, and if cooperative learning was effective for them. Specific strategy scores were mixed in with less-than-positive opinions of cooperative learning as a whole.

A study in computer science classes, the nature of the learning environment was conducted by Barker, Garvin-Doxas and Jackson (2002). The researchers performed a survey about many aspects of our teaching and student learning to determine our students' attitudes about collaborative learning. A 30-item online questionnaire was sent to 196 of our second and third-year undergraduate students, and 103 students responded. Students said they spent 28 percent of their time working with others on average. There was a positive linear link between the students' self-perceived communication talents and their confidence in working with others. These findings suggest that communication skills have an impact on group confidence and enjoyment. Academics may boost student confidence and enjoyment when it comes to working with others by providing structured collaboration opportunities that assist the development of communication skills.

Thanh (2011) looked into how Vietnamese teachers and students thought about cooperative learning. The study looked at how cooperative learning (CL) is implemented in Vietnamese classrooms, how local instructors and students felt about it, and what local impediments were in the way of its adoption. A questionnaire regarding CL was completed by forty teachers and forty students from twenty Vietnamese colleges, and follow-up interviews were conducted with 10 students and ten teachers to learn more about their perspectives on the practice. CL has been a popular and preferred technique of training in Vietnam, ac- 
cording to the findings. The purposes of CL, on the other hand, were frequently misunderstood since teachers and students believed that CL was primarily used to help pupils recall information rather than gain a thorough knowledge of the book they were studying.

Students' perceptions of adopting collaborative learning as a technique for acquiring writing abilities at university were investigated by Sedhu, Choy and Lee (2015). The study looked at how English-as-a-second-language (ESL) students felt about using group discussion as a collaborative learning method when studying writing skills at university. Group conversations have been demonstrated to improve students' learning experiences and knowledge in studies on collaborative learning. According to the findings, students claimed collaborative learning helped them reflect on the content and context of the tasks they had to complete. This kind of education was deemed to increase their confidence and motivation to communicate with their colleagues in a second language, and task completion rates were higher.

\subsubsection{Benefits Students Derive from Their Engagement in Collaborative Learning}

When collaborative learning is well-structured, it provides tremendous benefits for both students, regardless of the shape it takes in the classroom. While establishing a learner-centered environment, collaborative learning aids teachers in classroom management and provides an alternative instructional strategy (Cangelosi, 2000; Sharan \& Sharan, 1994). Collaborative learning appears to improve students' managerial (Good \& Brophy, 2000), social (Johnson \& Johnson, 1992), and academic skills (Wohl \& Klein-Wohl, 1994). Collaborative learning activities, according to Cangelosi (2000), promote student participation in lessons, help students build intrinsic drive, resolve student issues, and reduce disruptive behavior.

Cooperative learning, according to Good and Brophy (2000), increases students management abilities by emphasizing student accountability for one another. Each student has a task in the group, and group work cannot be accomplished unless each task is completed and coordinated with others. Several cooperative learning tasks, such as arranging resources, keeping the group on task, keeping track of time, and following orders, appear to be elements that assist students enhance their management skills (Baloche, 1998).

Students build social skills through cooperative learning, according to Kagan and Kagan (1994). Students grow to understand, respect, and support one another when cooperative learning is implemented, according to them. Cooperative learning also enhances students' self-esteem, allows them to form positive interpersonal interactions, and creates positive interdependence, according to previous studies in the subject (Johnson \& Johnson, 1992).

Collaborative learning helps students gain higher-level academic skills in a variety of subjects. In language arts, Wohl and Klein-Wohl (1994) claim that, cooperative learning activities help students gain good communication skills by 
simulating real-life scenarios in the classroom. Collaborative learning, according to Stahl et al. (1995), promotes students to interact, ask and answer questions, solve issues, and make decisions. Collaborative learning activities, according to Stahl et al. (1995), may be effective in teaching reading since they strengthen students' academic skills in language arts such as synthesizing, generalizing, summarizing, drawing conclusions, and distinguishing relevant and irrelevant ideas. Second language learners have possibilities to develop their academic skills while cooperatively studying reading materials, according to Jacob, Rottenberg, Patrick and Wheeler (1996).

\subsubsection{Challenges Students Face in Their Engagement in Collaborative Learning}

Teachers and students identified hurdles to effective student collaboration, according to a study done by Le, Janssen and Wubbels (2018). In this study, 19 teachers and 23 students from various disciplines at a university in Vietnam's pre-service teacher education faculty were interviewed. These programs prepare instructors for primary and secondary schools around the country. Students' lack of collaborative abilities, free-riding, competence level, and friendship were identified as four typical hurdles to collaboration based on grounded theory analysis.

However, Imel (1991) shows that the group work environment is plagued with issues, and he refutes the notion that successful group abilities can be developed simply by providing students with more opportunities to work in groups. Concerns about group work evaluation (Gatfield, 1999), rivalry for high marks (Imel, 1991), and dealing with the intricacies of group dynamics can all lead to tensions (Johnson \& Johnson, 1994). In many circumstances, group work has been shown to be significantly less productive than it could be, and students must be taught how to be effective group members, according to Homan and Poel (1999). There are a variety of reasons why group work can result in less-than-satisfactory involvement and outcomes. Competition, group dynamics, assessment, and inadequate group work organization are just a few of them.

As learners adjust to the dynamics of group work, collaborative work necessitates considerable adjustments to traditional learning approaches. This is not an easy undertaking, as Bosworth and Hamilton (1994) point out. Collaborative learning necessitates active participation from students as well as the completion of novel and frequently difficult cognitive and social tasks. It's understandable that pupils don't always react positively to this opportunity. Group work can provoke tensions, according to Miller, Trimbur and Wilkes (1994), and as a result, students may be confused or even apprehensive about their work in a collaborative classroom and how they will be graded. Mutch (1998) also observes that the tension students experience while working in groups often foreshadows what they will face in the workplace; and Finnegan and O'Mahony (as cited in Nour \& Yen, 1992), who discovered that group decision making in organizations necessitates increased levels of communication, coordination, and collaboration, 
and that this type of decision making generates more creativity. Such findings highlight the fact that group work can be emotionally and intellectually exhausting, despite the fact that supporters and practitioners of group work frequently ignore this fact. Individuals thrust into the difficult task of working with others, sometimes strangers, require time, experience, and motivation to work through the stages of group work, which include "forming, norming, storming, and performing" (Mutch, 1998). When ego clashes lead to dysfunctional group dynamics, a group may never be able to execute a task adequately through a collaborative effort.

Universities are inherently competitive, and academic grades are heavily weighted. "One of the main difficulties of group work projects is the lecturer or tutor's giving of marks for each member's contribution," Gatfield (1999) writes. Normally, the marker does not have access to each group member's understanding of their participation in all aspects of the project. Despite this, the group has a much better understanding of each member's relative contribution. There is an underlying notion that simply being a part of a group will teach you group skills, and regrettably, no formal or informal instruction on group conduct or interpersonal dynamics is provided (Johnson \& Johnson, 1991). Furthermore, groups may be formed without respect for personality, life experience, talent, or aptitude, resulting in a successful mix of persons emerging by happy accident rather than design.

\section{Research Methods}

\subsection{Research Design}

The study used a descriptive survey approach to collect data from participants in order to analyse the utilization of collaborative learning among University of Cape Coast B. Ed. Management students. The descriptive survey design was chosen for this study because it allows researchers to examine specific features, attitudes, feelings, beliefs, motives, behaviour, and views of a population, large or small, without attempting to influence any variables (Aborisade, 1997). It is adaptable and useful, especially for educators, in that it identifies current conditions and needs (Osuala, 2001). He goes on to add that descriptive research is essential for all sorts of research because it allows researchers to examine the situation and draw findings and recommendations.

\subsection{Sampling Technique}

The study's target demographic was all University of Cape Coast B. Ed. Management students. The study's target demographic, however, was University of Cape Coast level 200 - 400 B. Ed. Management students. Only students in levels 200 - 400 of the B. Ed. Management program were included in the study since they had spent more time in school than level 100 students. According to the Student Records and Management Information System (SRMIS) Unit (2017), the total number of B. Ed Management students at the University of Cape Coast 
ranged from level 200 to 400 . Table 1 shows a breakdown of the pupils based on their gender and academic level. The study drew a total of 245 B. Ed Management students from the University of Ghana. Bartlett, Kotrlik and Higgins (2001) formula for estimating sample size affected the researcher's decision to pick 245 individuals from a group of $542 \mathrm{~B}$. Ed Management students. According to Bartlett, Kotrlik, and Higgins (2001), the minimal sample size from a population of 600 people is 235 . To boost external validity, the researchers used $245 \mathrm{~B}$. Ed Management students in the study.

\subsection{Demographic Characteristics of the Respondents}

The demographic characteristics of the B. Ed Management students who participated in the study are discussed in this section. Gender and age were among the demographic features of the students studied in this section. These demographic characteristics were crucial in this study since they helped with the examination of the research hypothesis. Again, these demographic variables were deemed relevant since they would help readers better comprehend the type of respondents that took part in the study. Table 2 summarizes the findings.

The gender distribution of the students who took part in the study is shown in Table 2. The table shows that 144 students (58.7\%) were males and 101 students (41.3\%) were females. This suggests that more men than women took part in the research. Table 2 also listed the age groups of the students who took part in the study. As shown in the table, 178 (72.6\%) were between the ages of 21 and 25, 37 (15.1\%) were under the age of 20 , and $30(12.4 \%)$ were either 26 or older. This meant that the majority of the pupils who took part in the study were old enough to provide appropriate responses.

Table 1. Distribution of the population for the study.

\begin{tabular}{ccc}
\hline Level & Population & Sample \\
\hline 200 & 173 & 80 \\
300 & 188 & 85 \\
400 & 180 & 80 \\
Total & 541 & 245 \\
\hline
\end{tabular}

Source: Student Records and Management Information System (SRMIS) Unit (2020).

Table 2. Background information of respondents.

\begin{tabular}{ccc}
\hline Variable & Sub-scale & Frequency (\%) \\
\hline \multirow{2}{*}{ Gender } & Male & $144(58.7)$ \\
& Female & $101(41.3)$ \\
\hline \multirow{2}{*}{ Age of students } & Below 20 years & $37(15.1)$ \\
& $21-25$ years & $178(72.6)$ \\
& Above 26 years & $30(12.3)$ \\
\hline
\end{tabular}




\subsection{Data Collection Instrument}

The respondents were polled using a questionnaire that they devised themselves. According to Creswell (2002), a questionnaire is a document that participants in a study fill out and return to the researcher as part of a survey design. Participants mark options to questions and provide basic personal or demographic information, according to the author. According to Best and Kahn (2003), a questionnaire is a type of inquiry that includes a systematically created and arranged set of questions that will be distributed to population samples. When information is needed, Best and Kahn (2003) recommend using a questionnaire. They go on to say that, if correctly created and administered, the questionnaire may be a very effective and valuable data collection tool in a research study because it covers a wider range of topics. The questionnaire's reliability was measured using the test-retest method, which showed a good reliability coefficient of $r=0.85$ using Pearson product moment correlation. This shows that the instrument's internal consistency is deemed fit for the study

All of the questions in the survey will be closed-ended. "Strongly agree" (SA), "Agree" (A), "Uncertain" (U), "Disagree" (D), and "Strongly Disagree" (D) were the five Likert-type scales (SD). The Likert scale, according to Ary, Jacobs \& Razavieh (1990), is one of the most extensively used techniques for measuring attitudes. The demographic features of the respondents were asked about in Section A of the questionnaire. Section B gathered data on B. Ed. Management students' attitudes toward collaborative learning at the University of Cape Coast. Section $C$ gathered data on the advantages that collaborative learning provides $B$. Ed. Management students at the University of Cape Coast. Section D elicited data on the obstacles that B. Ed. Management students at the University of Cape Coast confront when participating in collaborative learning.

\subsection{Data Processing and Analysis}

The field data was compiled, sorted through, and revised to address queries that had only been partially answered or had not been answered at all. The openended questions were coded after they were edited (i.e., the assignment of numbers or codes to responses to make them computer readable). The data was entered into the computer using the Statistical Package for the Social Sciences (SPSS) software after editing and coding. After that, the data was analyzed and displayed in frequency and percentages, as well as mean and standard deviations.

\section{Results and Discussion}

This section discusses the data collected in the field in order to answer the research questions that were created to lead the study. A four-point Likert scale questionnaire was given to the student-teachers in order to answer the research questions that led the study. Following that, the questionnaire was analysed using the mean of the means and standard deviations. A mean of 3.0 and 
above indicates that the respondents agree with the statement, whereas a mean of 2.9 and below indicates that the respondents disagree with the statement. When the standard deviation is less than 1.0, the responses of the respondents are homogenous, and when it is greater than 1.0, the responses are heterogeneous.

\subsection{Research Question One: What Is the Perception of the B. Ed Management Students' towards Use of Collaborative Learning in the Learning of B. Ed Management?}

The goal of the first study question was to find out how students felt about using collaborative learning as a pedagogical strategy in B. Ed Management teaching and learning. Table 3 shows the students' perspectives, which were collected by a five-point Likert-scale questionnaire.

The students' perspectives on collaborative learning as a teaching and learning strategy were given in Table 3. The evidence from the Table (Mean $=4.1, \mathrm{SD}=$ 1.1) clearly shows that the students have a favourable attitude toward collaborative learning. For example, the students agreed that they gladly participate in collaborative activities (Mean $=3.7, \mathrm{SD}=1.3$ ). Again, the students agreed (Mean $=4.6, \mathrm{SD}=1.6)$ that they must learn to deal with pupils who are not like them. This suggests that kids are willing to join organizations regardless of the circumstances (Sedhu, Choy, \& Lee, 2015). As a result, students are more inclined to establish groups with their peers, regardless of their social, emotional, or physical makeup. As a result, the students alluded to the fact that they prefer professors to use more group activities/assignments (Mean $=4.3$, $\mathrm{SD}=.81$ ). Kids' desire to be a part of collaborative learning groups is a solid indicator that teachers can use to help shape students into engaged members of society. According to Thanh (2011), most teachers are leaning toward using a collaborative learning technique to teach their subject because it is preferred by students. This is because, according to the respondents (Mean $=4.5, \mathrm{SD}=.97$ ), collaborative learning allows them to socialize more with their colleagues. This is also likely to improve or instil in students positive working connections (Mean $=4.3, \mathrm{SD}=.81$ ). Students are likely to gain from their participation in collaborative learning activities in a number of ways. It can help students achieve more than they would as individuals (Mean $=4.2, \mathrm{SD}=1.0$ ), improve their attitude toward work (Mean $=3.8, \mathrm{SD}=.67)$, increase class engagement $(\mathrm{Mean}=4.2, \mathrm{SD}=.74)$, foster creativity (Mean $=4.0, \mathrm{SD}=.78)$, and make learning easier (Mean $=3.7, \mathrm{SD}=1.2)$. Students are more likely to prefer collaborative learning over other teaching and learning strategies because of these advantages. This study's findings back up what we already know. Students have been encouraged to develop creative work as well as inspire critical thinking through collaborative learning in the form of group discussions. Students' interpersonal abilities and social interactions improve as a result of this type of learning (Barker, Garvin-Doxas, \& Jackson, 2002). 
Table 3. Perception of the students towards the use of collaborative learning in the learning of B. Ed. management.

\begin{tabular}{lrr}
\hline Statement & MeanSD \\
\hline Participating in collaborative activities is something I enjoy doing. & 3.7 & 1.3 \\
I achieve more when I collaborate with other students than when I work alone. & 4.2 & 1.0 \\
Collaborative learning has the potential to improve my work attitude. & 3.8 & .67 \\
Collaborative learning encourages me to interact with others more. & 4.5 & .97 \\
Collaborative learning fosters positive student-teacher connections. & 4.3 & .81 \\
Collaborative learning encourages students to participate more actively in class.4.2 & .74 \\
In a group situation, creativity is aided. & 4.0 & .78 \\
Group activities make learning more enjoyable. & 3.7 & 1.2 \\
I'm learning how to collaborate with students that aren't like me. & 4.2 & 1.6 \\
When I work with other students, I have a better time with the content. & 3.6 & 1.5 \\
When I work in a group, my work is more organized. & 4.6 & 1.5 \\
My teachers could employ more group activities and tasks, in my opinion. & 4.3 & .81 \\
Mean of Means/Average Standard Deviation & 4.1 & 1.1 \\
\hline
\end{tabular}

\subsection{Research Question Two: What Benefits Do B. Ed. Management Students in the University of Cape Coast Derive from Their Engagement in Collaborative Learning?}

The purpose of this study was to see how collaborative learning affected students' academic performance in B. Ed Management. Table 4 summarizes the responses of the students on this study question.

Table 4 depicted the students' perspectives on the impact of collaborative learning on their academic performance. The Table shows that collaborative learning does have an impact on students' academic achievement (Mean $=4.5, \mathrm{SD}$ $=.71)$. For example, the students agreed (Mean $=3.9, \mathrm{SD}=1.6$ ) that when they work in groups, they gain more material than when they are taught in other ways. This suggests that, when compared to the learner-centered approaches commonly used by lecturers in teaching, the employment of collaborative learning methodologies improves students' intellectual skills. The students believed that using collaborative learning methodologies improved their academic performance (Mean $=3.9, \mathrm{SD}=.49$ ). The shift in their attitude toward education as a result of the usage of collaborative learning methodologies is partially responsible for their improved academic achievement. Collaborative learning increases their attitude about education, as agreed (Mean $=4.9, \mathrm{SD}=.88$ ). This is expected, given that when a learner-centered approach to teaching is utilized, students are more likely to feel linked to the entire educational enterprise than when other ways to teaching the topic are used. The students agreed (Mean = $4.6, \mathrm{SD}=.35$ ) that collaborative learning fosters a more learner-centered culture in the classroom, as shown in the Table. Students may take the lead in learning the subject once a leaner-centered atmosphere is established in the classroom, which will undoubtedly affect their performance. 
Table 4. Benefits students derive from collaborative learning.

\begin{tabular}{lrr}
\hline Statement & Mean & SD \\
\hline $\begin{array}{l}\text { I learn more information than when I engage in group work than when } \\
\text { taught with other methods. }\end{array}$ & 3.9 & 1.6 \\
Collaborative learning improves my attitude towards education. & 4.9 & .88 \\
Collaborative learning creates more learner-centred atmosphere & 4.6 & .35 \\
Collaborative learning improves my academic skills. & 3.9 & .49 \\
Collaborative learning enhances good working relationships among students. 4.6 & 1.2 \\
Collaborative learning enhances class participation. & 4.6 & .49 \\
Collaborative learning activities provide student engagement in lessons. & 4.7 & .45 \\
Group activities help students develop intrinsic motivation. & 4.4 & 1.0 \\
Collaborative learning reduces disruptive behaviours of students. & 4.4 & .72 \\
Collaborative learning contributes to solutions for conflicts among students. & 4.6 & .49 \\
Collaborative learning improves students' self-esteem. & 4.8 & .43 \\
Collaborative learning teaches management skills. & 4.7 & .48 \\
Mean of Means/Average Standard Deviation & 4.5 & .71 \\
\hline
\end{tabular}

Furthermore, the students agreed (Mean $=4.4, \mathrm{SD}=1.0$ ) that group activities aid in the development of intrinsic motivation and prevent disruptive behaviour among students (Mean $=4.4, \mathrm{SD}=.72)$. The outcomes of this study back up Cangelosi's (2000) assertion that collaborative learning activities aid in the development of intrinsic motivation in pupils. The intrinsic drive that students get as a result of group activities means that they will be more committed in the classroom, which will lessen the disruptive behaviours that they exhibit when group activities are not supported. When there are no disruptive behaviours in the classroom, teachers will have more time to teach their subjects. Disruptive behaviour is also likely to be reduced, since kids may have learned management skills as a result of their participation in group activities. According to the findings, students believed that collaborative learning improves management skills (Mean $=4.7, \mathrm{SD}=.48)$. This study's findings back up those of Good and Brophy (2000), who found that collaborative learning, improves students' managerial skills. Because students may generate solutions to student disagreements (Mean $=4.6, \mathrm{SD}=.49$ ), these management abilities are likely to grow. This would increase student engagement in class exercises even more (Mean $=4.6, \mathrm{SD}=.49$ ). As demonstrated by Cangelosi (2000), the utilization of collaborative learning activities adds to solutions for disagreements among students and minimizes disruptive behaviours of students.

\subsection{Research Question Three: What Challenges Do B. Ed. Management Students in the University of Cape Coast Face in Their Engagement in Collaborative Learning?}

The third study question was to discover the obstacles that students face when participating in collaborative learning activities. Table 5 summarizes the responses of the students on this study question. 
Table 5. Challenges students face in collaborative learning activities.

\begin{tabular}{ccc}
\hline Statement & Mean & SD \\
\hline Achieving consensus & 4.58 & .21 \\
Communication with group members & 4.22 & .17 \\
Coordination between group members & 4.48 & .20 \\
Lack of leadership & 4.78 & .09 \\
Lack of motivation & 4.43 & .12 \\
Lack of time & 3.59 & .19 \\
Meeting deadlines & 3.89 & .12 \\
Procrastination & 3.94 & .17 \\
Scheduling conflicts & 4.43 & .12 \\
Unequal participation & 3.59 & .19 \\
Mean of Means/Average Standard Deviation & 4.19 & .52 \\
\hline
\end{tabular}

Table 5 depicted the students' perspectives on the problems they face during collaborative learning activities. The students face a variety of problems in their group participation, as shown in the table (Mean of Mean $=4.19$, Average SD $=.52)$. For example, the students agreed (Mean $=4.58, \mathrm{SD}=.21)$ that obtaining consensus in their group activities is difficult. This suggests that the pupils as a whole don't agree on everything. This is to be expected, given that group dynamics may include people from various backgrounds, all of which are likely to influence how they interact in groups. The absence of unanimity in the group also implies that the students will have difficulty connecting with their peers and coordinating their efforts.

Furthermore, the students agreed (Mean $=4.78, \mathrm{SD}=.09$ ) that lack of leadership is an issue in their group activities. This could be due to the fact that each student is more likely to want to be in a position of leadership than their peers According to Johnson and Johnson (1991), it is more likely that groups will be established without much regard for personality, life experience, skill, or aptitude, and that a successful mix of persons will be achieved by happy accident than design. This condition is likely to cause friction among the group's members. The students acknowledged that scheduling difficulties is another challenge they have in the group (Mean $=4.3, \mathrm{SD}=.12$ ). In addition, a lack of leadership in the organization is likely to result in unequal engagement from all members. They are confronted with the problem of unequal engagement in the group, as evidenced (Mean $=3.59, \mathrm{SD}=.19$ ). There is a nagging feeling that the lack of leadership will have an impact on how the group conducts its operations. Meeting deadlines (Mean $=3.89, \mathrm{SD}=.12)$, procrastination $($ Mean $=3.94, \mathrm{SD}=.17)$, a lack of time $($ Mean $=3.59, \mathrm{SD}=.19)$, and a lack of motivation (Mean $=4.43$, $\mathrm{SD}=.12$ ) are all challenges that the respondent has, according to the data. The entire purpose of collaborative learning would be pointless unless these issues 
among students are addressed. As a result, it is reasonable to conclude that the barriers to collaborative learning include a lack of collaborative abilities, freeriding, competence status, and friendship (Le, Janssen, \& Wubbels, 2018).

\section{Conclusion}

Students' willingness to engage in the learning activity academically, emotionally, and actively appears to be a key factor in student engagement, according to the research. Active participation in collaborative learning activities (behavioural engagement), an intention to develop a personal appreciation of the value of learner engagement for learning outcomes (intellectual engagement), and emotional development are the core aspects of a fully developed learner engagement approach or profile (affective engagement). However, its value as a teaching and learning technique will not be realized until appropriate procedures are put in place to ensure that students' engagement in collaborative learning activities is successful. Furthermore, the manner in which students articulated their opinions and perspectives on learning outcomes and engagement suggests a link between the two. Students' self-reports, in particular, demonstrate that active engagement can help students achieve the desired learning goals.

\section{Recommendations and Further Suggestions}

Based on the key findings that emerged from the study, the following recommendations were made:

1) The academic board of the University of Cape Coast's Department of Business Education should evaluate B. Ed Management to make teacher-centered techniques such as collaborative learning a major pedagogy for B. Ed Management teaching and learning. This would ensure that students are energetically engaged in the teaching and the process of learning.

2) The University of Cape Coast's B. Ed Management lecturers should make a concerted effort to use collaborative learning as a teaching technique. This can be accomplished by offering students group exercises on a regular basis to guarantee that they develop the ability to collaborate with their classmates.

3) The University of Cape Coast's Training and Development Division should organize in-service training for B. Ed Management lecturers on how to effectively employ collaborative learning as an approach for teaching B. Ed Management.

4) The Department of Business Education should hold seminars and workshops to teach students how to collaborate with one another. This would reduce the difficulties students have when participating in group activities.

The following areas for further literature are proposed to further the study in this field.

1) A bigger sample size should be used in a comprehensive study on the same topic so that the results can be generalized. Lecturers could be included in such a study to compare their responses to the responses of the students. 
2) The study should be replicated using different research methods to verify if the results are the same. The mixed method approach, in particular, would add to the complementarity of the instruments utilized in this investigation.

\section{Conflicts of Interest}

The authors declare no conflicts of interest regarding the publication of this paper.

\section{References}

Aborisade, F. (1997). Research Methods. Multifirm Ltd. Publishers.

Ary, D., Jacobs, L. C., \& Razavieh, A. (1990). Introduction to Research in Education (4th ed.). Holt, Rinehart and Winston Inc.

Baloche, L. (1998). The Cooperative Classroom: Empowering Learning. Prentice Hall.

Barker, L. J., Garvin-Doxas, K., \& Jackson, M. (2002). Defensive Climate in the Computer Science Classroom. ACM SIGCSE Bulletin, 34, 43-47. https://doi.org/10.1145/563517.563354

Bartlett, J. E., Kotrlik, J. W., \& Higgins, C. C. (2001). Organizational Research: Determining Appropriate Sample Size in Survey Research. Information Technology, Learning, and Performance Journal, 19, 43-50.

Best, J., \& Kahn, J. (2003). Educational Research. Sage.

Bosworth, K., \& Hamilton, S. J. (1994). Editors' Notes. New Directions for Teaching and Learning, 59, 1-3. https://doi.org/10.1002/t1.37219945902

Cangelosi, J. S. (2000). Classroom Management Strategies (4th ed.). John Wiley \& Sons, Inc.

Carson, L. (1990). Cooperative Learning in the Home Economics Classroom. Journal of Home Economics, 82, 37-41.

Covington, M. V. (1992). Making the Grade: A Self-Worth Perspective on Motivation and School Reform. Cambridge University Press. https://doi.org/10.1017/CBO9781139173582

Creswell, J. W. (2002). Educational Research: Planning, Conducting, and Evaluating Quantitative (p. 676). Prentice Hall.

Dansereau, D. F. (1988). Cooperative Learning Strategies. In C. E. Weinstein, E. T. Goetz, \& P. A. Alexander (Eds.), Learning and Study Strategies (pp. 103-120). Academic Press. https://doi.org/10.1016/B978-0-12-742460-6.50013-X

Davidson, N., \& Major, C. H. (2014). Boundary Crossings: Cooperative Learning, Collaborative Learning, and Problem-Based Learning. Journal on Excellence in College Teaching, 25, 7-55.

Dishon, D., \& O’Leary, P. (1984). A Guidebook for Cooperative Learning: A Technique for Creating More Effective Schools. Learning Publications.

Enu, J., Asominiwa, L., \& Obeng, P. (2015). Effects of Group Size on Students Mathematics Achievement in Small Group Setting. British Journal of Education, 3, 58-64.

Gatfield, T. (1999). Examining Student Satisfaction with Group Projects and Peer Assessment. Assessment \& Evaluation in Higher Education, 24, 365-377.

https://doi.org/10.1080/0260293990240401

Good, T., \& Brophy, J. E. (2000). Motivating Students to Learn. Routledge. 
Homan, R. M., \& Poel, C. J. (1999). Developing Interactive Group Skills through Cooperative Learning. Sage.

Hossain, A., \& Tarmizi, R. A. (2013). Effects of Cooperative Learning on Students' Achievement and Attitudes in Secondary Mathematics. Procedia-Social and Behavioral Sciences, 93, 473-477. https://doi.org/10.1016/j.sbspro.2013.09.222

Imel, S. (1991). Collaborative Learning in Adult Education. ERIC Digest No. 113.

Jacob, E., Rottenberg, L., Patrick, S., \& Wheeler, E. (1996). Cooperative Learning: Context and Opportunities for Acquiring Academic English. TESOL Quarterly, 30, 253-280. https://doi.org/10.2307/3588143

Johnson, B., \& Christensen, L. (2012). Educational Research: Quantitative, Qualitative, and Mixed Approaches (4th ed.). SAGE Publications, Inc.

Johnson, D. W., \& Johnson, F. P. (1991). Joining Together: Group Theory and Group Skills. Prentice-Hall, Inc.

Johnson, D. W., \& Johnson, R. T. (1987). Learning Together and Alone: Cooperative, Competitive, and Individualistic Learning. Prentice-Hall, Inc.

Johnson, D. W., \& Johnson, R. T. (1992). Implementing Cooperative Learning. Contemporary Education, 63, 173-180.

Johnson, D. W., \& Johnson, R. T. (1994). Learning Together and Alone. Cooperative, Competitive, and Individualistic Learning. Allyn and Bacon.

Johnson, D. W., Johnson, R. T., Holubec, E. J., \& Roy, P. (1984). Circles of Learning: Cooperation in the Classroom. Association for Supervision and Curriculum Development.

Kagan, H., \& Kagan, J. (1994). Flexible Grouping Strategies in the Multi-Age Classroom. Theory into Practice, 41, 47-52. https://doi.org/10.1207/s15430421tip4101 8

Kerka, S. (1990). Job-Related Basic Skills. ERIC Digest No. 94.

Le, H., Janssen, J., \& Wubbels, T. (2018). Collaborative Learning Practices: Teacher and Student Perceived Obstacles to Effective Student Collaboration. Cambridge Journal of Education, 48, 103-122. https://doi.org/10.1080/0305764X.2016.1259389

Le, H., Janssen, J., \& Wubbels, T. (2018). Collaborative Learning Practices: Teacher and Student Perceived Obstacles to Effective Student Collaboration. Cambridge Journal of Education, 48, 103-122. https://doi.org/10.1080/0305764X.2016.1259389

McKeachie, W. J. (1978). Teaching Tips: A Guidebook for the Beginning College Teacher. DC Heath.

Miller, J. E., Trimbur, J., \& Wilkes, J. M. (1994). Group Dynamics: Understanding Group Success and Failure in Collaborative Learning. New Directions for Teaching and Learning, 1994, 33-44. https://doi.org/10.1002/tl.37219945906

Mutch, A. (1998). Employability or Learning? Group Work in Higher Education. Education + Training, 40, 50-56. https://doi.org/10.1108/00400919810206884

Nour, M. A., \& Yen, D. (1992). Group Decision Support Systems: Towards a Conceptual Foundation. Information \& Management, 23, 55-64. https://doi.org/10.1016/0378-7206(92)90008-4

Nwosu, A., Mason, S., Roberts, A., \& Hugel, H. (2013). The Evaluation of a Peer-Led Question-Writing Task. The Clinical Teacher, 10, 151-154. https://doi.org/10.1111/j.1743-498X.2012.00632.x

Osuala, E. C. (2001). Introduction to Research Methodology. Africana-Fep Publishers Ltd.

Phipps, M., Phipps, C., Kask, S., \& Higgins, S. (2001). University Students' Perceptions of Cooperative Learning: Implications for Administrators and Instructors. Journal of EX- 
periential Education, 24, 14-22. https://doi.org/10.1177/105382590102400105

Piaget, J. (1964). Part I: Cognitive Development in Children: Piaget Development and Learning. Journal of Research in Science Teaching, 2, 176-186. https://doi.org/10.1002/tea.3660020306

Sedhu, D. S., Choy, S. C., \& Lee, M. Y. (2015). Students' Perceptions of Using Collaborative Learning as a Tool for Acquiring Writing Skills in University. American Journal of Applied Psychology, 4, 1-6. https://doi.org/10.11648/j.ajap.s.2015040301.11

Sharan, Y., \& Sharan, S. (1994). Group Investigation in the Cooperative Classroom. In S. Sharan (Ed.), Handbook of Cooperative Learning Methods (pp. 97-114). Greenwood Press.

Slavin, R. E. (1991). Synthesis of Research of Cooperative Learning. Educational Leadership, 48, 71-82.

Slavin, R. E. (1995). Cooperative Learning: Theory, Research, and Practice (2nd ed.). Allyn \& Bacon.

Stahl, G., Sumner, T., \& Repenning, A. (1995). Internet Repositories for Collaborative Learning: Supporting Both Students and Teachers. The First International Conference on Computer Support for Collaborative Learning, Bloomington IN, October 1995, 321328. https://doi.org/10.3115/222020.222819

Stevens, R. J., \& Slavin, R. E. (1995). The Cooperative Elementary School: Effects on Students' Achievement, Attitudes, and Social Relations. American Educational Research Journal, 32, 321-351. https://doi.org/10.3102/00028312032002321

Thanh, P. T. H. (2011). An Investigation of Perceptions of Vietnamese Teachers and Students toward Cooperative Learning (CL). International Education Studies, 4, 3-12. https://doi.org/10.5539/ies.v4n1p3

Veenman, S., Denessen, E., van den Akker, A., \& Van Der Rijt, J. (2005). Effects of a Cooperative Learning Program on the Elaborations of Students during Help Seeking and Help Giving. American Educational Research Journal, 42, 115-151. https://doi.org/10.3102/00028312042001115

Vygotsky, L. (1978). Interaction between Learning and Development. Readings on the Development of Children, 23, 34-41.

Walling, D. R. (1987). A Model for Teaching Writing: Process and Product. Fastback 256. Phi Delta Kappa.

Wohl, A., \& Klein-Wohl, E. (1994). Teaching and Learning the Language Arts with Cooperative Learning Methods. In S. Sharan (Ed.), Handbook of Cooperative Learning Methods (pp. 177-192). Greenwood Press.

You, J. W., \& Kang, M. (2014). The Role of Academic Emotions in the Relationship between Perceived Academic Control and Self-Regulated Learning in Online Learning. Computers \& Education, 77, 125-133. https://doi.org/10.1016/j.compedu.2014.04.018 